\title{
Androgen receptor gene methylation related to colorectal cancer risk
}

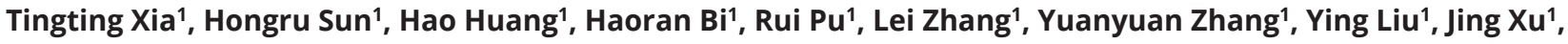 \\ Justina Ucheojor Onwuka', Yupeng Liu', Binbin Cui' ${ }^{2}$ and Yashuang Zhao ${ }^{1}$ \\ 'Department of Epidemiology, Public Health College, Harbin Medical University, Harbin, Heilongjiang Province, People's Republic of China \\ ${ }^{2}$ Department of Colorectal Surgery, The Third Hospital of Harbin Medical University, Harbin, Heilongjiang Province, People's Republic of China
}

\begin{abstract}
According to its incidence patterns, colorectal cancer (CRC) tends to occur more frequently in males than in females, and the evidence shows that CRC is a hormone-related tumor. These findings indicate that androgen receptor $(A R)$ gene methylation might be important for the regulation of the CRC risk in the different sexes. We used a case-control study to investigate the association between $A R$ methylation in peripheral blood $(\mathrm{PBL})$ and $C R C$ risk. A cohort study was conducted to analyze the effect of $A R$ methylation levels in both PBL and tissue on the prognosis of CRC. AR methylation levels were detected using methylation-sensitive high-resolution melting (MS-HRM). The results indicate that the hypomethylation of $A R$ was significantly associated with the risk of CRC (OR $=1.869,95 \% \mathrm{Cl}$ : 1.629-2.141, $P<0.001)$, and the results remained similar after adjusting for the propensity score (PS) $(\mathrm{OR}=1.344,95 \% \mathrm{Cl}: 1.147-1.575, P<0.001)$ and $\mathrm{PS}$ matching $(\mathrm{OR}=1.138,95 \%$ $\mathrm{Cl}: 1.000-1.292 P=0.049)$. The hypomethylation of $A R$ was significantly associated with CRC in males $(\mathrm{OR}=2.309,95 \% \mathrm{Cl}: 1.200-4.245 ; P=0.012)$ but not females $(\mathrm{OR}=1.000,95 \% \mathrm{Cl}$ : 0.567-1.765; $P=0.999$ ). The methylation status of $A R$ in $\mathrm{PBL}$ and tissue does not seem to be associated with prognosis in colorectal cancer $(\mathrm{OR}=1.425,95 \% \mathrm{Cl}$ : $0.895-2.269, P=0.135$; $\mathrm{OR}=0.930,95 \% \mathrm{Cl}: 0.674-1.285, P=0.661)$. We conclude that $A R$ hypomethylation in PBL is associated with a high risk of CRC and may serve as a biomarker. Further studies involving large sample sizes are needed to validate the results of this study.
\end{abstract}

\section{Key Words \\ - methylation \\ - androgen receptor \\ - peripheral blood \\ - colorectal cancer \\ - propensity scores}

\section{Introduction}

Worldwide, colorectal cancer (CRC) remains among the top three prevalent tumors among women and men according to Global Cancer Statistics with an estimated 1.4 million new cases and 693,900 deaths occurring in 2012 (1). Meanwhile, the 5-year relative survival rate of CRC patients in all stages combined was $65 \%$ as estimated by current CRC statistics in the United States in 2019 (2). Recently, CRC is gradually being considered as a hormone-related malignancy, and accumulating evidence suggests that sex hormones are relevant to its development (3). There is an observational phenomenon and clinical evidence suggesting that men tend to have a much higher risk of CRC than women of the same age (4).

As one of the most important sex hormones, androgens seem to exert most of their biological actions through the AR. Furthermore, ARs are present in colorectal tissue and reportedly participate in the differentiation, proliferation and progression of CRC tissues $(5,6)$. Recently, a longer CAG repeat sequence in exon 1 of the $A R$ gene was found to increase the risk of colorectal cancer (7), but Javier Quilez found that genes containing polymorphic tandem repeats (TRs) exhibit higher variance accompanied by DNA methylation (8). Additionally, methylation of

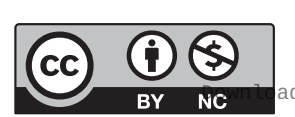

This work is licensed under a Creative Commons Attribution-NonCommercial 4.0 International License. ded from Bioscientifica.com at 04/26/2023 11:03:17AM 
HpaII and HhaI sites near the polymorphic CAG repeats was reported in the human $A R$ gene (9).

Research has revealed that the development of CRCs is due to multistep processes as a consequence of the accumulation of both mutations and epigenetic modifications of genes (10). However, only $5-6 \%$ of CRC cases are due to inherited conditions, which are denoted as CRC genetic syndromes, predisposing individuals to develop the disease (11). Meanwhile, only 20-25\% of CRC patients have a family history, suggesting that the remaining CRC cases (75-80\% of all cases) occur sporadically as a result of complex interactions between genetic and epigenetic susceptibility and environmental factors (12).

The development of CRC involves alterations not only in tumor tissues but also other organ systems, including the immune system $(13,14)$. Leukocytes serve as a major component of immunology and have the advantages of easy access and detection. Analyses have shown that abundant inflammatory cells are recruited to the tumor microenvironment, which is called immune infiltration and has been proven to be critical in CRC (15). Several studies focusing on the methylation of DNA in peripheral blood have revealed that this alteration might directly be a biomarker of the risk and prognosis of cancer $(16,17,18)$. Recently, studies have focused on the role of $A R$ in prostate (19), breast (20), hepatocellular, pancreatic and bladder cancers (21). However, few studies have reported the relationship between methylation in $A R$ and the risk and prognosis of CRC, even though in a recent epidemiology study, CRC was identified as a hormone-dependent tumor (22). Therefore, we hypothesized that methylation of $A R$ is associated with the risk and prognosis of CRC.

Here, we first investigated the association between $A R$ gene methylation in leukocytes in blood and its interaction with environmental factors and the risk of CRC in a casecontrol study. We also designed a cohort study to explore the association between $A R$ gene methylation in both PBL and tissue and the prognosis of CRC.

\section{Materials and methods}

\section{Study subjects}

We identified 378 CRC patients who underwent surgery at the Department of Colorectal Surgery of the Third Affiliated Hospital of Harbin Medical University, and all patients were diagnosed based on pathology. Patients with malignant melanomas, non-Hodgkin's lymphoma,

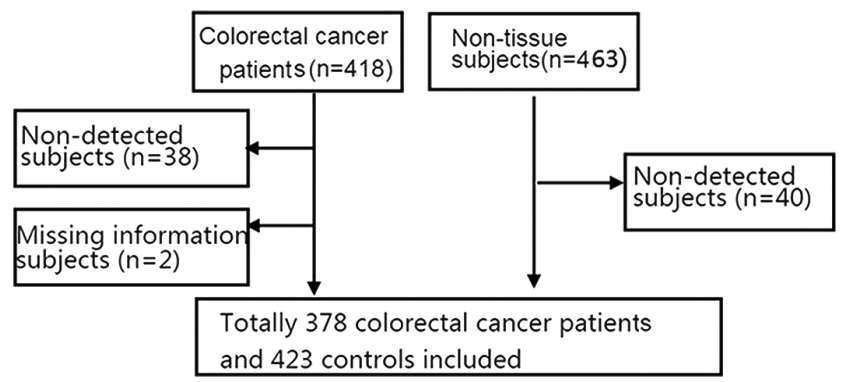

Figure 1

Flow chart of the participant inclusion in the case-control study.

gastrointestinal stromal tumors, metastatic CRC (not suitable for surgery) and Lynch syndrome CRC were excluded. In total, 423 control subjects were recruited from the Department of Orthopedics and Ophthalmology at the Second Affiliated Hospital of Harbin Medical University during the same period (Fig. 1). Patients with gastrointestinal disease were excluded. Samples of peripheral blood (approximately $5 \mathrm{~mL}$ ) were obtained from all subjects either before surgery for the cases or after enrollment but before treatment for the controls and immediately stored at $-80^{\circ} \mathrm{C}$.

Tumor tissue specimens were collected during surgery, rapidly frozen in liquid nitrogen after removal, sent to the lab and immediately stored at $-80^{\circ} \mathrm{C}$. We included 307 patients from The Tumor Hospital of Harbin Medical University and carried out a cohort study to investigate the relationship between $A R$ methylation in both PBL and tissue and prognosis in CRC. The patients were followed up at 3- to 6-month intervals during the first year after resection and annually thereafter. Clinical information regarding Dukes' stage, chemotherapy and the histological and pathological types was collected from the medical records. The overall survival (OS), which was defined as the time from surgery to the patient's death or final follow-up visit, was used as a measure of prognosis. The date of the final follow-up was March 15, 2014 (the 109th month). The rate of loss to follow-up was $16.6 \%$ (Fig. 2).

\section{Ethical approval}

This study was carried out after obtaining written informed consent from the study subjects and approval from the Human Research and Ethics Committee of Harbin Medical University; therefore, this study was performed in accordance with the ethical standards stipulated in the 1964 Declaration of Helsinki and its subsequent amendments.

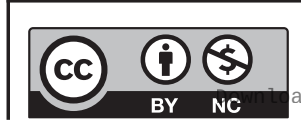




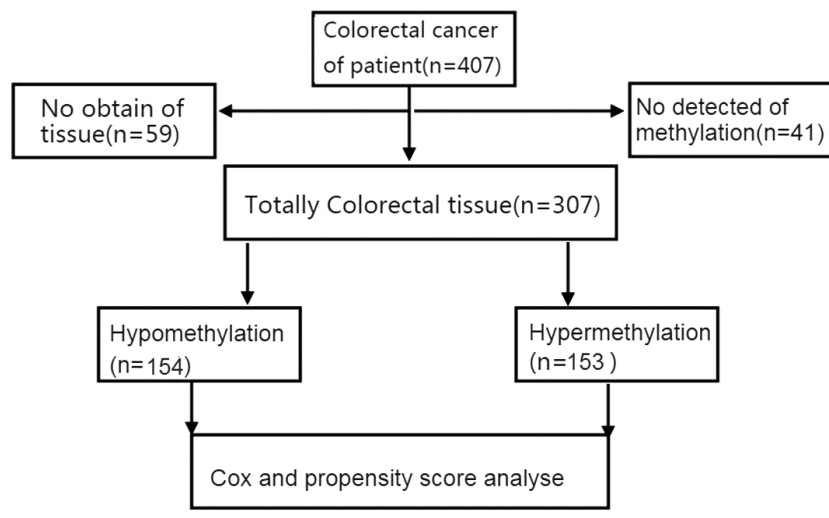

Figure 2

Flow chart of the participant inclusion in the cohort study.

\section{Analysis of the methylation status of $A R$}

After successfully extracting genomic DNA from the peripheral blood samples and tumor tissue and applying sodium bisulfite modification, a methylationsensitive high-resolution melting analysis (MS-HRM) was performed on a LightCycler480 machine (Roche Applied Science) with Gene Scanning Software (version 2.0 ) to detect and analyze the methylation status of $A R$. HRM was performed in a $10 \mu \mathrm{L}$ volume system consisting of $5 \mu \mathrm{L}$ of LightCycler480 High-Resolution Melting Master Mix (Roche), $0.25 \mu \mathrm{L}$ of each primer, $1.4 \mu \mathrm{L}$ of $\mathrm{MgCl}_{2}$ and $0.6 \mu \mathrm{L}$ of a sodium bisulfite-modified DNA template. The final volume system contained $2.5 \mu \mathrm{l}$ of PCR-grade water. The following primers were designed for the MS-HRM analysis to amplify the target area of chrX: 66766140-66766240 (hg19) located at exon 1 of AR using Primer Premier 5.0 software: forward primer 5'-CGTTCGTATTAAGTTGGAGAA-3' and reverse primer 5'-ACAAACTCGCCAAATCCCC-3'. The PCR amplification protocol consisted of denaturation for $10 \mathrm{~min}$ at $95^{\circ} \mathrm{C}$ for one cycle; a two-step amplification method (referred to as preamplification) at $59^{\circ} \mathrm{C}$ for seven cycles, followed by $52^{\circ} \mathrm{C}$ for 50 cycles and extension lasting for $10 \mathrm{~s}$ at $72^{\circ} \mathrm{C}$. In the melting protocol, the amplified fragments were propitious to $64-94^{\circ} \mathrm{C}$ with 40 signal acquisitions per degree and cooling at $40^{\circ} \mathrm{C}$ for $10 \mathrm{~s}$.

A series of universal methylated (100\% methylated) and unmethylated ( $0 \%$ methylated) human whole genomic DNA samples (Zymo Research) was used as a calibrator (100, 25, 10, 5, 2, 1 and 0\% methylated DNA) by diluting the samples to different proportions with PCRgrade water (Fig. 3). In addition to these standards, nonDNA water was carefully added to each plate as a negative control, and all reactions were performed in duplicate.
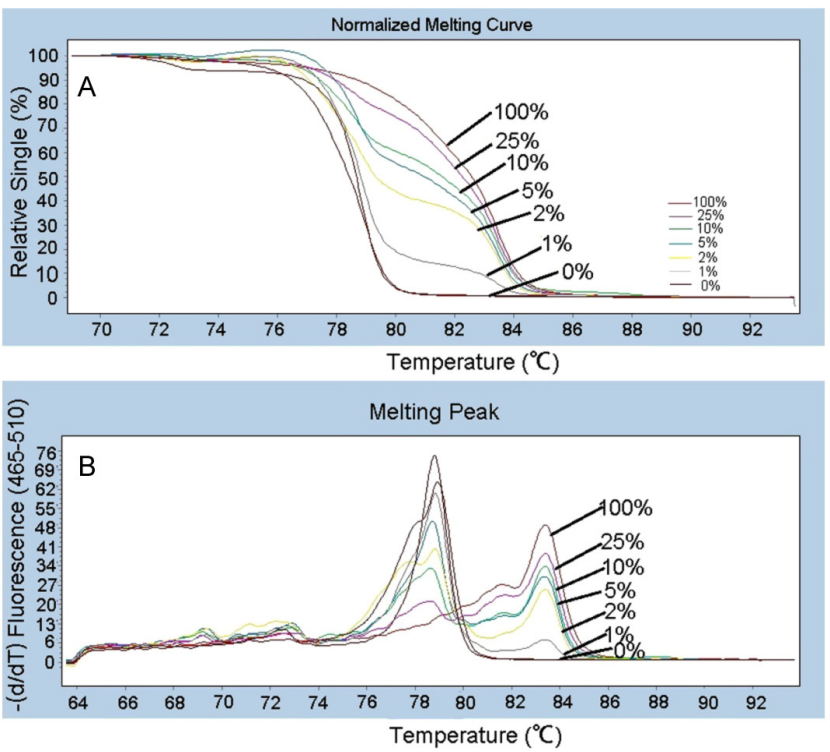

Figure 3

Methylation-sensitive high-resolution melting (MS-HRM) for the detection of PBL AR methylation in standard samples. (A) Standard curves used in the AR MS-HRM assay. (B) Fluorescence profile obtained the melting temperature of serial dilutions of methylated DNA $(100,25,10,5,2,1$ and $0 \%)$ from the $A R$ gene.

The HRM data, including the temperature shift, normalization and different plots, were analyzed using the software module mentioned above. The methylation status of $A R$ was determined by comparing the melting curves of each sample to the series of standard dilutions in the gene scanning module, which was performed by two independent observers. Disagreements were settled by consensus or a third opinion. Based on the methylation level in PBL and tumor tissue, we used the ROC curve to determine the methylation cut-off point, which was 5 and $25 \%$, respectively. A methylation level in the $A R$ gene higher than the cut-off point was defined as hypermethylation; otherwise, the level was defined as hypomethylation.

\section{Statistical analyses}

To test the statistical significance of the continuous variables, we chose two-sample $t$-tests, and for the categorical variables, we used chi-square $\left(\chi^{2}\right)$ tests. Univariate and multivariate logistic regressions were applied to calculate the crude and adjusted estimate ORs and 95\% CIs of the associations among environmental factors, $A R$ methylation in PBL DNA and their interaction with CRC risk. The combined effects of the environment factors and methylation were analyzed by a crossover analysis. The OS was estimated using the life table

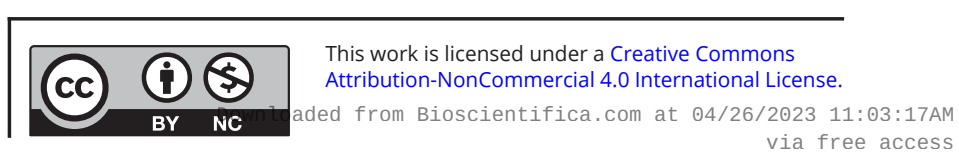


method. The prognosis of patients considering the $A R$ methylation and survival status was analyzed with a Cox proportional hazard regression model that generated HRs (hazard ratios) and 95\% CIs to assess the potential factors affecting the survival time. Missing values were imputed via multiple imputation, and then the PS was calculated to control for potential confounding factors. All statistical analyses were performed using SPSS version 19.0, and $P$ values $<0.05$ were considered statistically significant.

\section{Result validation}

We used an external GEO dataset of the EPIC-Italy study involving 590 participants (166 cases and 424 controls) and methylation levels detected by an Infinium Human Methylation450Bead chip (HM450, Illumina) to validate our results (Supplementary Fig. 1, see section on supplementary data given at the end of this article). EPIC-Italy is a multi-center prospective cohort study from the European Prospective Investigation into Cancer and Nutrition designed to investigate the risk of frequent cancers, such as colorectal cancer. This study recruited 47,749 volunteers (15,171 males and 32,578 females) between 1993 and 1998 from five districts in Italy (23). After each participant signed an informed consent form, questionnaires were used to conduct the survey, and blood samples were taken and recorded at the center (24).

\section{Results}

\section{Basic demographic characteristics of the cases and controls}

This case-control study comprised 378 CRC patients (230 male and 148 female) and 423 (219 male and 204 female) controls. As shown in Table 1, statistically significant differences were observed in age, gender, BMI, marriage status and educational levels; therefore, we adjusted for these variables and other possible confounding factors using the PS method. The variables adjusted by the PS method are shown in Supplementary Tables 1 and 2 . No significant differences were found in occupation and ethics between the cases and controls.

\section{Association between the methylation status of the $A R$ gene in PBL and the colorectal cancer risk}

Among the 801 total subjects, nearly two-thirds were successfully detected as having hypomethylation of $A R(68.9 \%)$. We utilized two PS methods to adjust for the association between $A R$ methylation and CRC risk. Hypomethylation of $A R$ was related to a higher risk of CRC by both the PS adjustment $(\mathrm{OR}=1.344$, 95\% CI: $1.147-1.575, P<0.001)$ and PS match adjustment methods $(\mathrm{OR}=1.138,95 \%$ CI: 1.000-1.292, $P=0.049)$ (Table 2). We used an external case-control study based on EPIC-Italy (GSE51032) to verify this association and achieved consistent results $(\mathrm{OR}=2.109, \quad 95 \% \quad \mathrm{CI}$ : 1.363-3.258, $P<0.001$ ) (Supplementary Table 3).

\section{Subgroup analysis of the associations between $A R$ gene methylation in PBL and the CRC risk}

Hypomethylation of $A R$ shows a statistically significant higher risk of $\mathrm{CRC}$ in males $(\mathrm{OR}=2.309,95 \% \mathrm{CI}$ : 1.200-4.245; $P=0.012)$ but not in females $(\mathrm{OR}=1.000$, 95\% CI: $0.567-1.765 ; \quad P=0.999)$. Subjects aged $\leq 60$ years, but not subjects older than 60 years, with hypomethylation of $A R$ present a higher risk of CRC $(\mathrm{OR}=1.744$, 95\% CI: 1.032-2.948; $P=0.038)$. The methylation status of $A R$ seems to present a risk of tumor location $(\mathrm{OR}=1.991$, 95\% CI: 1.160-3.416; $P<0.001$; $\mathrm{OR}=2.266,95 \% \mathrm{CI}: 1.519-3.380 ; P=0.103)$ but was not significant after the PS adjustment $(\mathrm{OR}=1.132,95 \% \mathrm{CI}$ : 0.625-2.051; $P=0.638$; OR=2.266, 95\% CI: 0.927-2.297; $P=0.103$ ) (Table 3 ). Our results are consistent with the conclusion drawn based on the subgroup analysis of the GEO dataset in males, i.e., males with hypomethylation of $A R$ tend to have a higher risk of CRC $(\mathrm{OR}=2.184,95 \% \mathrm{CI}$ : 1.093-4.363; $P=0.027)$; however, the results differ in females such that females with hypomethylation of $A R$ are also associated with an increased risk of CRC $\quad(\mathrm{OR}=1.996,95 \% \quad \mathrm{CI}: \quad 1.102-3.616 ; \quad P=0.023)$. Simultaneously, the group aged $\leq 60$ years also presented a higher risk $(\mathrm{OR}=2.524,95 \% \mathrm{CI}: 1.532-4.158 ; P<0.001)$, but no risk was observed in the subjects older than 60 years $(\mathrm{OR}=1.021,95 \% \mathrm{CI}: 0.399-2.612 ; P=0.965)$ (Supplementary Table 4).

\section{Interaction effect between environmental factors and $A R$ gene methylation on the CRC risk}

An antagonistic interaction effect between $A R$ hypomethylation and a higher intake of pungent food ( $>1$ day/month) on the risk of CRC was observed $\left(\mathrm{OR}_{\mathrm{i}}=0.505\right.$, 95\% CI: 0.259-0.986, $\left.P=0.045\right)$ (Supplementary Table 5). 
Table 1 Distribution of the characteristics of CRC patients and controls.

\begin{tabular}{l}
\hline Variables \\
\hline Age, years \\
Mean \pm S.D. \\
$\leq 50$ \\
$50-$ \\
$60-$ \\
$>70$ \\
Gender \\
Male \\
Female \\
BMl \\
Mean \pm s.D. \\
$<18.5$ \\
$18.5-$ \\
$\geq 23$ \\
Education \\
Primary school and below \\
Junior senior and above \\
Occupation \\
White collar \\
Blue collar \\
Marriage \\
Married \\
Others \\
Ethic group \\
Han \\
Others \\
Smoking \\
No \\
Yes \\
Drinking \\
No \\
Yes \\
Physical exercise \\
No \\
Yes \\
Family history of colorectal cancer \\
No \\
Yes \\
\hline \\
The
\end{tabular}

\begin{tabular}{c}
\hline No. of CRC $(n=378), \boldsymbol{n}(\%)$ \\
$60 \pm 11.292$ \\
$64(16.9 \%)$ \\
$123(32.5 \%)$ \\
$109(28.8 \%)$ \\
$82(21.8 \%)$ \\
$230(60.8 \%)$ \\
$148(39.2 \%)$ \\
$23.31 \pm 3.621$ \\
$29(7.7 \%)$ \\
$151(40.0 \%)$ \\
$198(52.3 \%)$ \\
$221(58.5 \%)$ \\
$157(41.5 \%)$ \\
$180(47.6 \%)$ \\
$198(52.4 \%)$ \\
$368(97.4 \%)$ \\
$10(2.6 \%)$ \\
$365(96.6 \%)$ \\
$13(3.4 \%)$ \\
$201(53.2 \%)$ \\
$177(46.8 \%)$ \\
$173(45.8 \%)$ \\
$205(54.2 \%)$ \\
$175(46.3 \%)$ \\
$203(53.7 \%)$ \\
$346(91.5 \%)$ \\
$32(8.5 \%)$ \\
\\
\\
\end{tabular}

\begin{tabular}{|c|c|}
\hline No. of control $(n=423), \boldsymbol{n}(\%)$ & P value $^{a}$ \\
\hline $\begin{array}{r}58 \pm 10.632 \\
89(21.0 \%) \\
134(31.7 \%) \\
135(31.9 \%) \\
65(15.4 \%)\end{array}$ & 0.012 \\
\hline $\begin{array}{l}219(51.8 \%) \\
204(48.2 \%)\end{array}$ & 0.010 \\
\hline $\begin{array}{c}24.52 \pm 4.114 \\
15(3.6 \%) \\
136(32.2 \%) \\
272(64.2 \%)\end{array}$ & $<0.001$ \\
\hline $\begin{array}{l}201(47.5 \%) \\
222(52.5 \%)\end{array}$ & 0.002 \\
\hline $\begin{array}{l}183(43.3 \%) \\
240(56.7 \%)\end{array}$ & 0.216 \\
\hline $\begin{array}{c}397(93.9 \%) \\
26(6.1 \%)\end{array}$ & 0.017 \\
\hline $\begin{array}{c}404(95.5 \%) \\
19(4.5 \%)\end{array}$ & 0.563 \\
\hline $\begin{array}{l}154(36.4 \%) \\
269(63.6 \%)\end{array}$ & $<0.001$ \\
\hline $\begin{array}{l}161(38.1 \%) \\
262(61.9 \%)\end{array}$ & 0.027 \\
\hline $\begin{array}{l}169(40.0 \%) \\
254(60.0 \%)\end{array}$ & 0.070 \\
\hline $\begin{array}{c}394(93.1 \%) \\
29(6.9 \%)\end{array}$ & $<0.001$ \\
\hline
\end{tabular}

a $P$ value calculated using Student's $t$-test for continuous variables or Pearson's chi-squared test for categorical variables.

\section{Association between $A R$ gene methylation in tissue and PBL and colorectal prognosis}

Genomic DNA from 307 colorectal tumor tissue samples was assessed for $A R$ methylation; the frequency of $A R$ hypermethylation was 50.49\% (155/307). The methylation status of the $A R$ gene does not seem to be associated with the prognosis of CRC (HR=0.930, 95\% CI: 0.674-1.285, $P=0.661)$. The analysis using the PS-matched adjustment method also shows the same results (HR $=0.969,95 \%$ CI: $0.803-1.168, P=0.738$ ). We also did not observe an association between the $A R$ gene methylation level in PBL and the prognosis of CRC (HR $=1.425,95 \%$ CI: 0.895-2.269, $P=0.135$ ) (Table 4). However, an association between $A R$ methylation in tissue and prognosis was observed in our external verification using the TCGA dataset $(\mathrm{HR}=3.485$, 95\% CI: $1.867-6.506 ; P<0.001 ; \quad H R=2.139,95 \%$ CI: 1.12-4.085; $P=0.021$ ) (Supplementary Table 6).

\section{Discussion}

Our study is the first to report that lowers methylation levels of $A R$ in PBL DNA are associated with an increased $\mathrm{CRC}$ risk. Furthermore, we found that hypomethylation in males is more likely to confer a risk of colorectal cancer. We found that hypomethylation in cg17964359 and $\operatorname{cg} 18156601$ (Fig. 4) of the $A R$ gene were significantly associated with CRC risk. The mean methylation of these two hypomethylation sites presents a similar risk of CRC 
Table 2 Associations between $A R$ gene methylation in PBL and CRC risk in different models.

\begin{tabular}{|c|c|c|}
\hline Methylation & $\begin{array}{c}\text { No. of CRC } \\
(n=378), \boldsymbol{n}(\%)\end{array}$ & $\begin{array}{l}\text { No. of control } \\
(n=423), \boldsymbol{n}(\%)\end{array}$ \\
\hline Hypermethylation & $91(24.1 \%)$ & $158(37.3 \%)$ \\
\hline Hypomethylation & 287 (75.9\%) & 265 (62.7\%) \\
\hline
\end{tabular}

\begin{tabular}{|c|c|}
\hline \multicolumn{2}{|c|}{ Unadjusted } \\
\hline OR $(95 \% \mathrm{Cl})$ & $P$ value $^{a}$ \\
\hline 1.000 & \\
\hline $1.869(1.629-2.141)$ & $<0.001$ \\
\hline
\end{tabular}

\begin{tabular}{c}
$\frac{\text { PS adjusted }}{\text { OR }(95 \% \mathrm{Cl})}$ \\
$\frac{P \text { value }^{\mathrm{b}}}{1.000}$ \\
$1.344(1.147-1.575)<0.001$ \\
\hline
\end{tabular}

$\begin{array}{cc}\frac{\text { PS matching adjusted }}{\mathrm{OR}(95 \% \mathrm{Cl})} & \frac{P \text { value }}{1.000} \\ \begin{array}{cc}1.138(1.000-1.292) & 0.049\end{array}\end{array}$

${ }^{a} P$ value calculated using unconditional logistic regression. ${ }^{b} P$ value calculated using propensity scores adjusted. ${ }^{c} P$ value calculated using propensity scores matching adjusted. Individuals with extreme propensity score are excluded (CRC, $n=133$ and control, $n=178$ ).

as our findings. Notably, we also found that a stronger CRC risk was significantly associated with $A R$ hypomethylation not only in males but also in females in the GEO dataset. This difference is most likely due to the limited number of female samples.

Studies have shown that males tend to develop colonic lesions at an earlier age than females (25). In addition, the beneficial role of exogenous estrogen and/or progestin use against the development of colorectal cancer has been consistently shown among postmenopausal women (26). A pool of data from four prospective cohort studies revealed an inverse association between the circulating levels of testosterone and CRC risk in men (27). Furthermore, studies have found that long-term androgen deprivation therapy for prostate cancer is associated with an increased risk of colorectal cancer (28).

In 1991, researchers detected androgen receptors in normal intestinal mucosa and paired tumor biopsy specimens and found an increased AR level in the tumor tissue (29). The intestinal epithelium accomplishes continuous renewal through a structure called cryptvillus units, which are involved in the dynamic process of stem cell migration to the surface of the epithelium (30). Recently, studies have confirmed that cell proliferation and apoptosis in the crypt-villus axis are regulated by the Wnt cascade, which can activate the classical b-catenin pathway and is involved in colon tissue selfrenewal (31). The cytoplasmic protein b-catenin plays the most important role in this mechanism. Truica et al. indicated that beta-catenin can significantly enhance the androgen-stimulated transcriptional activation of $A R$ and simultaneously increase $A R$ transcriptional activation by androstenedione. Furthermore, the AR protein assists in transporting beta-catenin into the nucleus when exposed to exogenous androgen (32).

Studies have shown that methylation in promoters can lead to gene silencing in CRC. Kimberly P verified that reducing methylation in $A R$ and increasing $A R$ mRNA and protein abundance controls the reaction to androgen sensitivity (33). Androgen, particularly testosterone, plays a significant role in the development of CRC since studies suggest that the indirect tumor-promoting effects of testosterone more likely explain the disparity between the sexes in the development of colonic adenomas (34). We hypothesized that a low level methylation in $A R$ in PBL can decrease the activation of AR and thus reduce the sensitivity to androgen and contribute to the risk of CRC. However, more evidence is needed in the future.

Table 3 Subgroup analysis for $A R$ methylation in PBL and CRC risk in different models.

\begin{tabular}{|c|c|c|c|c|c|c|}
\hline \multirow[b]{2}{*}{ Subgroup } & \multirow{2}{*}{$\begin{array}{c}\text { No. of hypomethylation, } \\
(n=552), \boldsymbol{n}(\%) \\
\text { No. case/no. control }\end{array}$} & \multirow{2}{*}{$\begin{array}{c}\text { No. of hypermethylation, } \\
(n=249), \boldsymbol{n}(\%) \\
\text { No. case/no. control } \\
\end{array}$} & \multicolumn{2}{|l|}{ Unadjusted } & \multicolumn{2}{|l|}{ PS adjusted } \\
\hline & & & OR $(95 \% \mathrm{Cl})$ & $P$ value ${ }^{a}$ & OR $(95 \% \mathrm{Cl})$ & $P$ value $^{\mathrm{b}}$ \\
\hline \multicolumn{7}{|l|}{ Gender } \\
\hline Male & 383 (69.4\% 207/176 & $66(26.5 \%) 23 / 43$ & $2.604(1.475-4.608)$ & 0.001 & $2.309(1.200-4.425)$ & 0.012 \\
\hline Female & 169 (30.6\%) 79/90 & 183 (73.5\%) 70/113 & $1.387(0.900-2.141)$ & 0.138 & $1.000(0.567-1.765)$ & 0.999 \\
\hline \multicolumn{7}{|l|}{ Age, years } \\
\hline$\leq 60$ & $282(51.1 \%)$ 144/138 & $131(52.6 \%)$ 44/87 & $2.211(1.408-3.473)$ & 0.001 & $1.744(1.032-2.948)$ & 0.038 \\
\hline$>60$ & $270(48.9 \%) 142 / 128$ & $118(47.4 \%)$ 49/69 & $1.569(1.002-2.458)$ & 0.049 & 1.041 (0.609-1.779) & 0.883 \\
\hline \multicolumn{7}{|l|}{ BMI } \\
\hline$<18.5$ & $33(6.0 \%)$ 20/13 & $11(4.4 \%)$ 9/2 & $2.542(0.411-15.715)$ & 0.312 & 4.207 (0.466-37.987) & 0.194 \\
\hline 18.5- & 208 (37.7\% 115/93 & $80(32.1 \%) 35 / 45$ & $0.627(0.369-1.066)$ & 0.085 & $0.684(0.367-1.275)$ & 0.232 \\
\hline$\geq 23$ & $311(56.3 \%)$ 152/159 & 158 (63.5\% 49/109 & 0.449 (0.297-0.678) & $<0.001$ & $0.653(0.398-1.069)$ & 0.090 \\
\hline \multicolumn{7}{|l|}{ Location } \\
\hline Colon & $66(12.0 \%)$ & $22(8.8 \%)$ & $1.991(1.160-3.146)$ & $<0.001$ & $1.132(0.625-2.051)$ & 0.638 \\
\hline Rectum & $154(27.9 \%)$ & $41(16.5 \%)$ & 2.266 (1.519-3.380) & $<0.001$ & 1.565 (0.927-2.297) & 0.103 \\
\hline
\end{tabular}

a $P$ value calculated using unconditional logistic regression. ${ }^{b} P$ value calculated using propensity scores adjusted.

https://ec.bioscientifica.com

https://doi.org/10.1530/EC-19-0122 (c) 2019 The authors Published by Bioscientifica Ltd

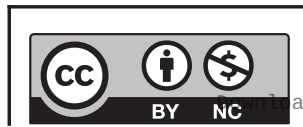

This work is licensed under a Creative Commons Attribution-NonCommercial 4.0 International License. ded from Bioscientifica.com at 04/26/2023 11:03:17AM via free access 


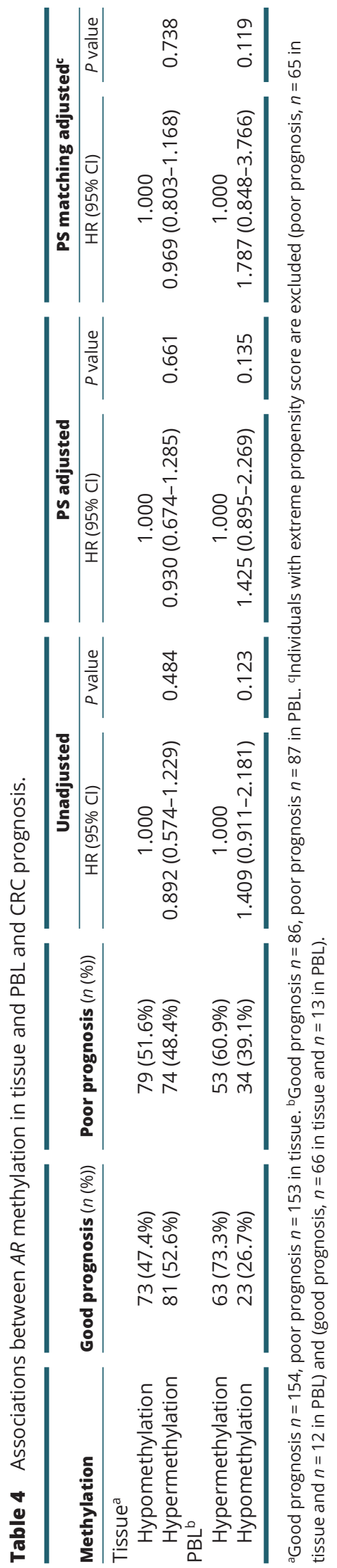

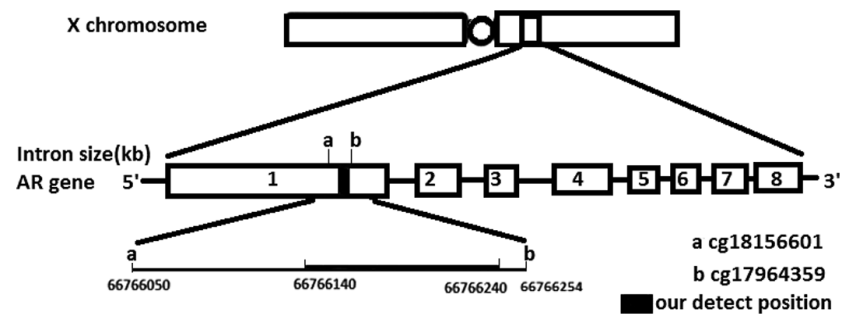

Figure 4

Position of the methylation probes in the AR gene from the HM450 BeadChip.

We found that younger ( $\leq 60$ years) patients presented a positive correlation between $A R$ hypomethylation and an increased $\mathrm{CRC}$ risk $(\mathrm{OR}=1.744)$ compared to older ( $>60$ years) patients. Interestingly, the same result was found in the GEO dataset in which younger hypomethylation patients showed a distinctly higher risk of CRC $(\mathrm{OR}=2.524)$. Increased levels of androgen were observed in the younger patients compared with those in the patients older than 60 years (35), which may have contributed to the high risk of CRC in the hypomethylation of $A R$ in young adults.

In our study, we observed a higher methylation level in the tumor tissue than that in the adjacent nontumoral tissue (Supplementary Fig. 2). Castagnetta and his colleague found that a discrepancy in the AR status between nontumoral and malignant human colorectal tissues was predominantly $67 \%$ positive in nontumoral tissues; in contrast, regarding malignant tissues, only $32 \%$ of cases had a positive AR status (36). We further examined the mean methylation status of $A R$ (cg17964359 and cg18156601) and the expression level in the TCGA dataset and found a weak inverse correlation $\left(\mathrm{r}_{\text {mean }}=-0.171\right.$, $P=0.001$ ) (Supplementary Fig. 3). Another dataset of 53 colorectal cancer cell lines also indicated a weak inverse correlation between methylation and expression levels ( $r=-0.261, P=0.059$ ) (Supplementary Fig. 4). The evidence shows that a high expression of $A R$ is associated with a poor prognosis in esophageal carcinoma and breast cancer patients $(37,38)$. However, research indicates that this phenomenon does not exist in gastric cancer (39). In our study, we did not find that a high level of $A R$ methylation is associated with a poor prognosis likely due to the limited sample size. However, this association was found in the TCGA dataset. Therefore, a large number of samples is recommended for further studies.

MS-HRM is a specific and sensitive assay that is easily applicable and enables the detection of as little as $0.1-1 \%$ of methylated DNA in a sample. This method can detect more CpG dinucleotide fragment lengths, suggesting that

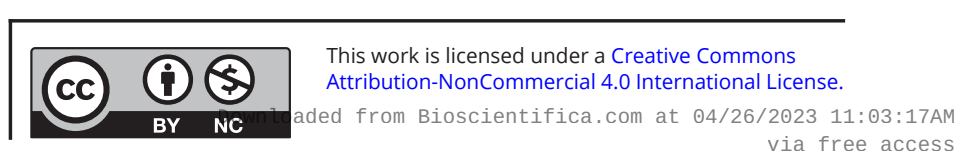


it possesses multisite consecutive judgment to obtain more accurate methylation detection signals, whereas only a limited CpG coverage by the primer is detected by Q-MSP $(40,41)$. Furthermore, the results of HRM are stable and not compromised by the heterogeneous methylation of particular CpGs, the design of primers and the incomplete conversion of samples (42); thus, this approach will hopefully be widely applied in the clinical setting for screening in the future.

However, there are still some limitations to our study. First, we did not distinguish the type of cells in PBL; nevertheless, a study focusing on the methylation levels of DNA in five different leukocyte subtypes suggested that different leukocyte subtypes might not affect the DNA methylation level in peripheral blood (43). Second, our research results are based on a case-control study and cannot provide confirmation regarding whether the methylation of $A R$ is a preparatory epigenetic event of CRC or a cancer-derived consequence; however, the GEO data are derived from a nested case-control study involving the prospective EPIC-Italy cohort in which methylation information was collected prior to the diagnosis of CRC. The results based on GEO strongly supported our findings. Additionally, we need to further explore the pathogenesis mechanism of $A R$ methylation and CRC risk.

In conclusion, our study provides a novel potential biomarker of the methylation alteration of $A R$ in PBL, and this phenomenon may contribute to the sex difference in CRC risk. We hope that more studies involving large samples will explore the relationship among $A R$ methylation, CRC risk and prognosis in the future.

\section{Supplementary data}

This is linked to the online version of the paper at https://doi.org/10.1530/ EC-19-0122.

\section{Declaration of interest}

The authors declare that there is no conflict of interest that could be perceived as prejudicing the impartiality of the research reported.

\section{Funding}

This work was supported by the National Natural Science Foundation of China grants, Grant numbers 81473055 and 30972539.

\section{Acknowledgements}

The authors thank Prof. Binbin Cui, Department of Colorectal Surgery, The Third Affiliated Hospital of Harbin Medical University, for his kind assistance in questionnaire and sample collection. They also thank Dr Haoran Bi and Rui Pu, Department of Epidemiology, Public Health College, Harbin Medical University, for their expert technical and life care in the research.

\section{References}

1 Torre LA, Bray F, Siegel RL, Ferlay J, Lortet-Tieulent J \& Jemal A. Global cancer statistics 2012. CA: A Cancer Journal for Clinicians 2015 65 87-108. (https://doi.org/10.3322/caac.21262)

2 Siegel RL, Miller KD \& Jemal A. Cancer statistics 2019. CA: A Cancer Journal for Clinicians 201969 7-34. (https://doi.org/10.3322/ caac.21551)

3 Lin JH \& Giovannucci E. Sex hormones and colorectal cancer: what have we learned so far? Journal of the National Cancer Institute 2010 102 1746-1747. (https://doi.org/10.1093/jnci/djq444)

4 Brenner H, Kloor M \& Pox CP. Colorectal cancer. Lancet 2014383 1490-1502. (https://doi.org/10.1016/S0140-6736(13)61649-9)

5 Berta L, Fronticelli BC, Fazzari A, Radice E, Bargoni A, Frairia R \& Gaetini A. Sex steroid receptors, secondary bile acids and colorectal cancer. Panminerva Medica 200445 261-266.

6 D'errico I \& Moschetta A. Nuclear receptors, intestinal architecture and colon cancer: an intriguing link. Cellular and Molecular Life Sciences 200865 1523-1543. (https://doi.org/10.1007/s00018-0087552-1)

7 Huang R, Wang G, Song Y, Wang F, Zhu B, Tang Q, Liu Z, Chen Y, Zhang $\mathrm{Q}$, Muhammad S, et al. Polymorphic CAG repeat and protein expression of androgen receptor gene in colorectal cancer. Molecular Cancer Therapeutics 201514 1066-1074. (https://doi. org/10.1158/1535-7163.MCT-14-0620)

8 Quilez J, Guilmatre A, Garg P, Highnam G, Gymrek M, Erlich Y, Joshi RS, Mittelman D \& Sharp AJ. Polymorphic tandem repeats within gene promoters act as modifiers of gene expression and DNA methylation in humans. Nucleic Acids Research 201644 3750-3762. (https://doi.org/10.1093/nar/gkw219)

9 Allen RC, Zonghbi HY, Moseley AB, Rosenblatt HM \& Belmont JW. Methylation of HpaII and HhaI sites near the polymorphic CAG repeat in the human androgen-receptor gene correlates with $\mathrm{X}$ chromosome inactivation. American Journal of Human Genetics 1992 51 1229-1239.

10 Migliore L, Migheli F, Spisni R \& Copped F. Genetics, cytogenetics, and epigenetics of colorectal cancer. Journal of Biomedicine and Biotechnology 20112011 792362. (https://doi. org/10.1155/2011/792362)

$11 \mathrm{Ma}$ H, Brosens LAA, Offerhaus GJA, Giardiello FM, de Leng WWJ \& Montgomery EA. Pathology and genetics of hereditary colorectal cancer. Pathology 201850 49-59. (https://doi.org/10.1016/j. pathol.2017.09.004)

12 Jasperson KW, Tuohy TM, Neklason DW \& Burt RW. Hereditary and familial colon cancer. Gastroenterology 2010138 2044-2058. (https:// doi.org/10.1053/j.gastro.2010.01.054)

13 Pernot S, Terme M, Voron T, Colussi O, Marcheteau E, Tartour E \& Taieb J. Colorectal cancer and immunity: what we know and perspectives. World Journal of Gastroenterology 201420 3738-3750. (https://doi.org/10.3748/wjg.v20.i14.3738)

14 Erodogan S, Yilmaz FM, Yazici O, Yozgat A, Sezer S, Ozdemir N, Uysal S, Purnak T, Sendur MA \& Ozaslan E. Inflammation and chemerin in colorectal cancer. Tumour Biology 201637 6337-6342. (https://doi.org/10.1007/s13277-015-4483-y)

15 Galon J, Costes A, Sanchez-Cabo F, Kirilovsky A, Mlecnik B, LagorcePages C, Tosolini M, Camus M, Berger A, Wind P, et al. Type, density, and location of immune cells within human colorectal tumors predict clinical outcome. Science 2006313 1960-1964. (https://doi. org/10.1126/science.1129139)

16 Brennan K, Garcia-Closas M, Orr N, Fletcher O, Jones M, Ashworth A, Swerdlow A, Thorne H; KConFab Investigators, Riboli EV, Riboli E, et al. Intragenic ATM methylation in peripheral blood DNA as a biomarker of breast cancer risk. Cancer Research 201272 2304-2313. (https://doi.org/10.1158/0008-5472.CAN-11-3157)

17 Fridley BL, Armasu SM, Cicek MS, Larson MC, Wang C, Winham SJ, Kalli KR, Koestler DC, Rider DN, Shridhar V, et al. Methylation

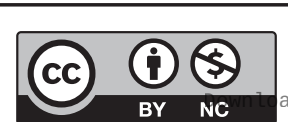

This work is licensed under a Creative Commons Attribution-NonCommercial 4.0 International License. ded from Bioscientifica.com at 04/26/2023 11:03:17Am 
of leukocyte DNA and ovarian cancer: relationships with disease status and outcome. BMC Medical Genomics 20147 21. (https://doi. org/10.1186/1755-8794-7-21)

18 Han Y, Xu J, Kim J, Wu X \& Gu J. Methylation of subtelomeric repeat D4Z4 in peripheral blood leukocytes is associated with biochemical recurrence in localized prostate cancer patients. Carcinogenesis 2017 38 821-826. (https://doi.org/10.1093/carcin/bgx064)

19 Culig Z \& Santer FR. Androgen receptor signaling in prostate cancer. Cancer Metastasis Reviews 201433 413-427. (https://doi.org/10.1007/ s10555-013-9474-0)

20 Feng J, Li L, Zhang N, Liu J, Zhang L, Gao H, Wang G, Li Y, Zhang Y, Li X, et al. Androgen and AR contribute to breast cancer development and metastasis: an insight of mechanisms. Oncogene 201736 2775-2790. (https://doi.org/10.1038/onc.2016.432)

21 Antonarakis ES. AR signaling in human malignancies: prostate cancer and beyond. Cancers 201810 22. (https://doi.org/10.3390/ cancers10010022)

22 Morch LS, Lidegaard Ø, Keiding N, Lokkegaard E \& Kjaer SK. The influence of hormone therapies on colon and rectal cancer. European Journal of Epidemiology 201631 481-489. (https://doi.org/10.1007/ s10654-016-0116-z)

23 Riboli E \& Kaaks R. The EPIC project: rationale and study design European Prospective Investigation into Cancer and Nutrition. International Journal of Epidemiology 199726 S6-14. (https://doi. org/10.1093/ije/26.suppl_1.s6)

24 Sieri S, Pala V, Brighenti F, Agnoli C, Grioni S, Berrino F, Scazzina F, Palli D, Masala G, Vineis P, et al. High glycemic diet and breast cancer occurrence in the Italian EPIC cohort. Nutrition, Metabolism, and Cardiovascular Diseases 201323 628-634. (https://doi.org/10.1016/j. numecd.2012.01.001)

25 Schoenfeld P, Cash B, Flood A, Dobhan R, Eastone J, Coyle W, Kikendall JW, Kim HM, Wiss DG, Emory T, et al. Colonoscopic screening of average-risk women for colorectal neoplasia. New England Journal of Medicine 2005352 2061-2068. (https://doi. org/10.1056/NEJMoa042990)

26 Murphy N, Strickler HD, Stanczyk FZ, Xue X, Wassertheil-Smoller S, Rohan TE, Ho GY, Anderson GL, Potter JD \& Gunter MJ. A prospective evaluation of endogenous sex hormone levels and colorectal cancer risk in postmenopausal women. Journal of the National Cancer Institute 2015107 10. (https://doi.org/10.1093/jnci/ djv210)

27 Lin JH, Zhang SM, Rexrode KM, Manson JE, Chan AT, Wu K, Tworoger SS, Hankinson SE, Fuchs C, Gaziano JM, et al. Association between sex hormones and colorectal cancer risk in men and women. Clinical Gastroenterology and Hepatology 201311 419.e1-424. e1. (https://doi.org/10.1016/j.cgh.2012.11.012)

28 Gillessen S, Templeton A, Marra G, Kuo YF, Valtorta E \& Shahinian VB. Risk of colorectal cancer in men on long-term androgen deprivation therapy for prostate cancer. Journal of the National Cancer Institute 2010102 1760-1770. (https://doi. org/10.1093/jnci/djq419)

29 Meggouh F, Lointier P, Pezet D \& Saez S. Status of sex steroid hormone receptors in large bowel cancer. Cancer 199167 1964-1970. (https://doi.org/10.1002/1097-0142(19910401)67:7<1964::AIDCNCR2820670724>3.0.CO;2-S)

30 Clevers H. Wnt/beta-catenin signaling in development and disease. Cell 2006127 469-480. (https://doi.org/10.1016/j. cell.2006.10.018)
31 van de Wetering M, Sancho E, Verweij C, de Lau W, Oving I, Hurlstone A, van der Horn K, Batlle E, Coudreuse D, Haramis AP, et al. The beta-catenin/TCF-4 complex imposes a crypt progenitor phenotype on colorectal cancer cells. Cell $2002111241-250$. (https://doi.org/10.1016/S0092-8674(02)01014-0)

32 Truica CI, Byers S \& Gelmann EP. Beta-catenin affects androgen receptor transcriptional activity and ligand specificity. Cancer Research 200060 4709-4713.

33 Keil KP, Abler LL, Laporta J, Altmann HM, Yang B, Jarrard DF, Hernandez LL \& Vezina CM. Androgen receptor DNA methylation regulates the timing and androgen sensitivity of mouse prostate ductal development. Developmental Biology 2014396 237-245. (https://doi.org/10.1016/j.ydbio.2014.10.006)

34 Roshan MH, Tambo A \& Pace NP. The role of testosterone in colorectal carcinoma: pathomechanisms and open questions. EPMA Journal 20167 22. (https://doi.org/10.1186/s13167-016-0071-5)

35 Kaufman JM \& Vermeulen A. The decline of androgen levels in elderly men and its clinical and therapeutic implications. Endocrine Reviews 200526 833-876. (https://doi.org/10.1210/er.2004-0013)

36 Castagnetta L, Traina A, Campisi I, Calabro M, Maratta A, Saetta A, Agostara B \& Mezzatesta N. Androgen receptor status in nontumoral and malignant human colorectal tissues. Annals of the New York Academy of Sciences 2002963 322-325. (https://doi. org/10.1111/j.1749-6632.2002.tb04124.x)

37 Dong H, Xu J, Li W, Gan J, Lin W, Ke J, Jiang J, Du L, Chen Y, Zhong X, et al. Reciprocal androgen receptor/interleukin-6 crosstalk drives oesophageal carcinoma progression and contributes to patient prognosis. Journal of Pathology 2017241 448-462. (https://doi. org/10.1002/path.4839)

38 Huang R, Han J, Liang X, Sun S, Jiang Y, Xia B, Niu M, Li D, Zhang J, Wang $S$, et al. Androgen receptor expression and bicalutamide antagonize androgen receptor inhibit $\beta$-catenin transcription complex in estrogen receptor-negative breast cancer. Cellular Physiology and Biochemistry 201743 2212-2225. (https://doi. org/10.1159/000484300)

39 Tang W, Liu R, Yan Y, Pan X, Wang M, Han X, Ren H \& Zhang Z. Expression of estrogen receptors and androgen receptor and their clinical significance in gastric cancer. Oncotarget 20178 40765-40777. (https://doi.org/10.18632/oncotarget.16582)

40 Hussmann D \& Hansen LL. Methylation-sensitive high resolution melting (MS-HRM). Methods in Molecular Biology 20181708 551-571. (https://doi.org/10.1007/978-1-4939-7481-8_28)

41 Draht MX, Smits KM, Jooste V, Tournier B, Vervoort M, Ramaekers C, Chapusot C, Weijenberg MP, van Engeland M \& Melotte V. Analysis of RET promoter CpG island methylation using methylationspecific PCR (MSP), pyrosequencing, and methylation-sensitive high-resolution melting (MS-HRM): impact on stage II colon cancer patient outcome. Clinical Epigenetics 20168 44. (https://doi. org/10.1186/s13148-016-0211-8)

42 Wojdacz TK \& Dobrovic A. Methylation-sensitive high resolution melting (MS-HRM): a new approach for sensitive and highthroughput assessment of methylation. Nucleic Acids Research 2007 35 e41. (https://doi.org/10.1093/nar/gkm013)

43 Zilbauer M, Rayner TF, Clark C, Coffey AJ, Joyce CJ, Palta P, Palotie A, Lyons PA \& Smith KG. Genome-wide methylation analyses of primary human leukocyte subsets identifies functionally important cell-type-specific hypomethylated regions. Blood 2013122 e52-e60. (https://doi.org/10.1182/blood-2013-05-503201)

Received in final form 27 May 2019

Accepted 6 June 2019

Accepted Preprint published online 6 June 2019 https://ec.bioscientifica.com https://doi.org/10.1530/EC-19-0122
(C) 2019 The authors Published by Bioscientifica Ltc

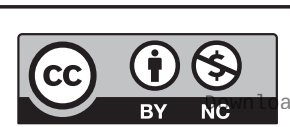

This work is licensed under a Creative Commons Attribution-NonCommercial 4.0 International License. ded from Bioscientifica.com at 04/26/2023 11:03:17AM 